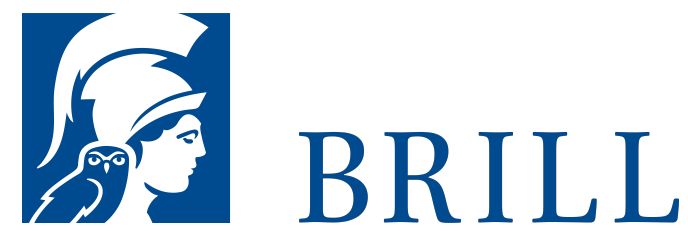

\title{
Menschenrechte zwischen moralischer Begründung und politischer Verwirklichung
}

Eine Neubetrachtung der Adressierung von

Menschenrechtspflichten

Author: Daniela Ringkamp

Dieses Buch analysiert das Spannungsfeld zwischen der normativen Begründung und der politischen Implementierung von Menschenrechten und greift dabei insbesondere auf die begrifflichen und legitimatorischen Implikationen moralischer und politischer Menschenrechtsbegründungen zurück. Ziel ist es, eine im Zuge der Aufwertung politischer Begründungskonzepte geäußerte Grundannahme zum Verhältnis von Menschenrechten und moralischen Rechten sowie zur Adressierung von Menschenrechtspflichten zu hinterfragen. Denn politischen Begründungen zufolge liegt der Unterschied zwischen Menschenrechten und moralischen Rechten vor allem in der Frage der Adressierung der entsprechenden Rechte: Während sich moralische Rechte primär an Einzelpersonen richten, sind Menschenrechtspflichten nicht an einzelne Individuen, sondern an Staaten und politische Institutionen adressiert. Durch eine Neubetrachtung moralischer Menschenrechtsbegründungen argumentiert das Buch jedoch dafür, neben Staaten, die eine zentrale Funktion beim Schutz von Menschenrechten einnehmen, in einigen Fällen auch einzelne Individuen als direkte Adressaten von Menschenrechtsansprüchen zu verstehen. Darüber hinaus wird versucht, das Verhältnis von Menschenrechten und moralischen Rechten neu auszulegen und den Unterschied beider Rechtsklassen weniger über die Adressierung, sondern über inhaltliche Kriterien zu definieren.

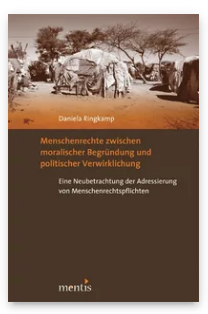

Pages: 257

Seiten

Language:

German

Subjects:

General, Philosophy

Publisher: Brill | mentis

E-Book (PDF)

Released online:

o1 Jan 2015

ISBN: $978-3-$

89785-641-7

List price

Paperback

Publication date:

o1 Jan 2015

ISBN: 978-3-

89785-846-6

List price 
For more information see brill.com

Order information: Order online at brill.com +44330 333 0049 | customerservices@brill.com Submission information: brill.com/authors

Titles published by Brill | Fink, Brill | mentis or Brill | Schöningh: +49(o)715413279216| brill@brocom.de 